Volume 3, Issue 2, pages 171-184

\title{
Alarm System and Emergency Message from Wheelchair User Emergency Condition
}

\author{
Yavez E. Loho ${ }^{1}$, Diana Lestariningsih ${ }^{1, *}$, Peter R. Angka ${ }^{1}$ \\ ${ }^{1}$ Department of Electrical Engineering, Faculty of Engineering, \\ Surabaya Widya Mandala Catholic University, Indonesia \\ *Corresponding Author: diana@ukwms.ac.id
}

(Received 12-09-2021; Revised 31-12-2021; Accepted 31-12-2021)

\begin{abstract}
When someone uses a wheelchair, there is still the possibility of an accident to the user, such as when the user suddenly falls down from the wheelchair or the user falls down along with the wheelchair. For notification of emergency conditions for wheelchair users, an alarm system is designed that can send messages to the intended mobile number. The system is designed using Wemos D1 mini, Ultrasonic, MPU-6050 and Proximity E18-D80NK sensors. The conclusion from the measurement and test results are: the value read by the MPU-6050 sensor is taken one axis for each direction when the wheelchair was falling down, $Y \leq 180^{\circ}$ for left falling down, $X \leq 50^{\circ}$ for right falling down, $Z \leq 65^{\circ}$ for forward falling and $Z \geq 140^{\circ}$ for backwards falling down. The Ultrasonic sensor works well for detecting the presence of user's legs and the E18-D80NK proximity sensor works well for detecting the position of the user who is sitting in a wheelchair. Receiving notifications through the BLYNK server works well, not affected by distance provided there is an internet connection connected to the device.
\end{abstract}

Keywords: Wheelchair, MPU-6050 sensor, ultrasonic sensor, emergency conditions, Wemos D1 mini 


\section{International Journal of Applied Sciences and Smart Technologies}

Volume 3, Issue 2, pages 171-184

p-ISSN 2655-8564, e-ISSN 2685-9432

\section{Introduction}

The use of wheelchairs in society is widely used to help people who have difficulty walking on their feet, either due to injury or disability. This tool is not only available in hospitals but is also sold in general at health outlets in every area. So it is relatively easy for people who have difficulty walking to buy a wheelchair. There are various types of wheelchairs, manual, electric, and sport. However, the most often found in the general public is the manual type because the price is affordable and its use is practical for ordinary people. The manual type wheelchair is moved by being pushed another person or by the user's own hand. In its use, it is often found that the safety of wheelchairs is not perfect. There are still many emergency conditions that occur in wheelchair users, such as when the user falls down from the wheelchair or the user falls along with the wheelchair. The cause of these emergency conditions can occur because the user moves excessively or it can also be due to the condition of the user being tired or weak and the lack of supervision of the user. For notification of the emergency condition of the wheelchair user, a warning device or notification is needed to other people when the wheelchair user at the emergency condition and so they can immediately provide assistance.

Several literature reviews that have been carried out relating to wheelchair safety systems are smart wheelchairs that can avoid obstacles by using 8 proximity sensors and cameras (Yeounggwang Ji, 2013). Electric wheelchair to avoid obstacles using the HCSR04 sensor where the wheelchair can detect obstacles less than 2m (Taizo Miyachi et al, 2016). The electric wheelchair safety system from impact uses 6 proximity sensors to detect obstacles (Darul, Muslimin, 2017). Automatic wheelchair with intelligent control mode and Wi - Fi placement system. A wheelchair specifically for users who have lowlevel visual impairment, by scanning the position of the wheelchair and controlling the direction of the wheelchair remotely (Manjunath, Gurukiran, 2018). From the reference review, what is being done is to maintain safety while using a wheelchair, whereas in the event of an emergency, a wheelchair user has not planned to report the emergency condition. Therefore, the purpose of this study is to design an alarm system for 


\section{International Journal of Applied Sciences and Smart Technologies}

Volume 3, Issue 2, pages 171-184

p-ISSN 2655-8564, e-ISSN 2685-9432

notification of emergency conditions for wheelchair users and send messages to telephone numbers that have been stored in advance.

The goal to be achieved is to produce a wheelchair alarm system that can provide notifications automatically when wheelchair user at emergency condition. The emergency condition is that the wheelchair user falls along with the wheelchair or the wheelchair user falls down without a wheelchair. So, further action can be taken from the notification recipient or the people around who hear the alarm sound. Note that readers are referred to published work [1], [2], [3], [4], [5], [6], [7], [8], and [9].

\section{Research Methodology}

This section provides research methodology that we use in this work.

\subsection{Block Diagram}

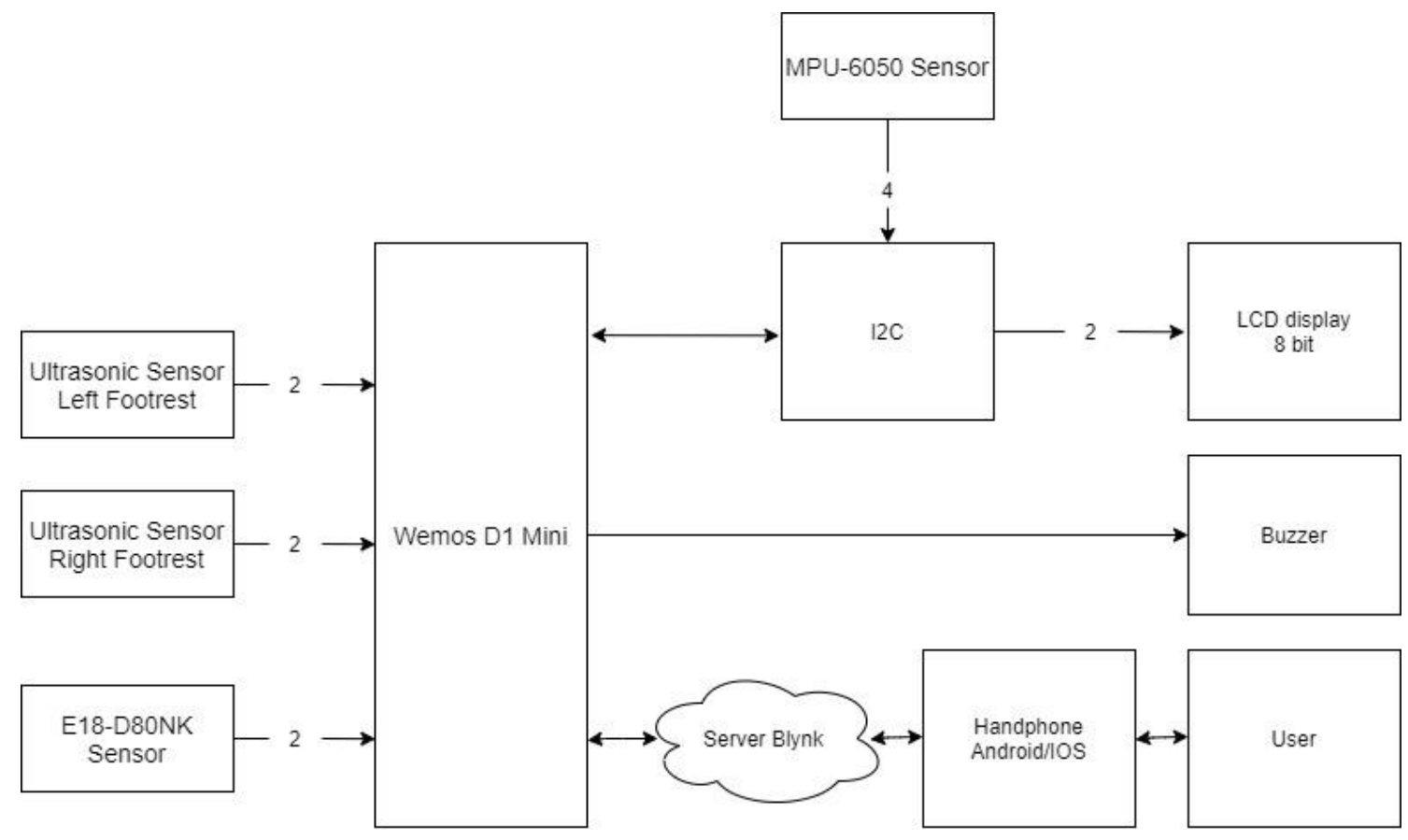

Figure 1. Block Diagram

Figure 1 shows a block diagram of the designed system. The overall working principle of the tool system is governed by the Wemos D1 mini as the main microcontroller. In the design of the tool there are 2 pairs of Ultrasonic Sensors which are placed on the pipe on the right and left side of the wheelchair footrest retainer and 


\section{International Journal of Applied Sciences and Smart Technologies}

Volume 3, Issue 2, pages 171-184

p-ISSN 2655-8564, e-ISSN 2685-9432

the Proximity E18-D80NK sensor on the right side of wheelchair seat and the MPU6050 sensor on the back side of the wheelchair.

Ultrasonic and proximity E18-D80NK sensor serves to detect the presence of users sitting in wheelchairs. Ultrasonic sensors on the right and left side pipes of the footrest supports are used to detect the user's legs with the soles of the feet in the wheelchair footrest position. When the user is about to get out of the wheelchair, the footrest is automatically opened and the ultrasonic sensor will detect the open footing and the Proximity E18-D80NK sensor on the right side of the wheelchair seat will detect there is no wheelchair user. This proves that the user left the wheelchair.

The MPU-6050 sensor on the wheelchair functions as a detector of a certain slope value to determine if the wheelchair is in a normal position or falling down. If the user falls along with the wheelchair, the MPU-6050 sensor will detect a change in the predetermined value indicating that the user is in an emergency condition and the Wemos D1 mini wifi module will send an emergency message in the form of a notification on BLYNK server to the target person's cellphone where the cellphone number is previously saved. Under certain conditions, wheelchair users may fall forward without a wheelchair. In this case, the ultrasonic sensor will detect that there is no user in a wheelchair so that the Wemos D1 mini Wifi Module will send an emergency notification to the target phone via BLYNK server.

The explanation of the system block diagram is as follows:

1. Wemos D1 mini is the main controller that functions to process all data and becomes communication from the device to BLYNK server to send notifications.

2. The MPU-6050 sensor is used to detect the tilt of the wheelchair when the user on the wheelchair at an emergency condition.

3. Ultrasonic sensors on the left and right side of the footrest supports are used to detect the user's legs with the soles of the feet in the wheelchair footrest position

4. The E18-D80NK Proximity Sensor functions to detect the presence of the user while sitting in a wheelchair.

5. Eight-bit LCD Display functions to display characters in the form of information on the position of wheelchair users and who can be contacted when wheelchair users are in an emergency condition. 


\section{International Journal of Applied Sciences and Smart Technologies}

Volume 3, Issue 2, pages 171-184

p-ISSN 2655-8564, e-ISSN 2685-9432

6. BLYNK server is used as an application to receive notifications from wheelchair users at emergency conditions.

\subsection{Hardware Design}

Figure 2 shows the placement of the black box at the back side of the wheelchair. The black box has dimensions of $18 \times 11 \times 6 \mathrm{~cm}$ containing the MPU-6050 sensor, Wemos D1 mini, and LCD Display. The MPU-6050 sensor is placed in a box that aims to keep at the stable position.

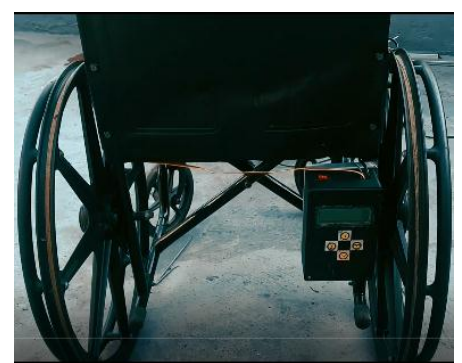

Figure 2. Black Box Placement at the back side of Wheelchair

Wemos D1 mini as a microcontroller functions to process data received from each sensor used. Wemos D1 mini is placed in a box with the aim of preventing circuit damage due to external factors such as accidental collisions. Figure 3 shows the position of the component placement.
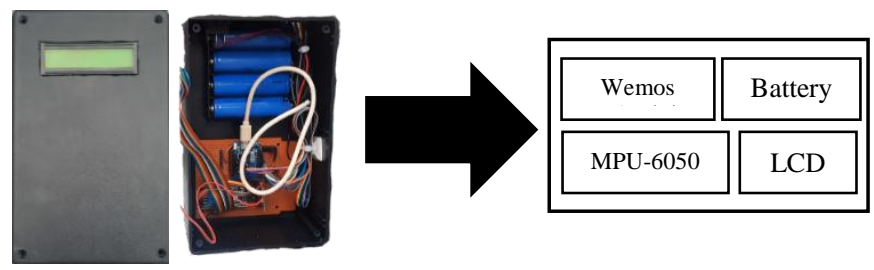

Figure 3. Components Position in Black Box 


\section{International Journal of Applied Sciences and Smart Technologies}

Volume 3, Issue 2, pages 171-184

p-ISSN 2655-8564, e-ISSN 2685-9432
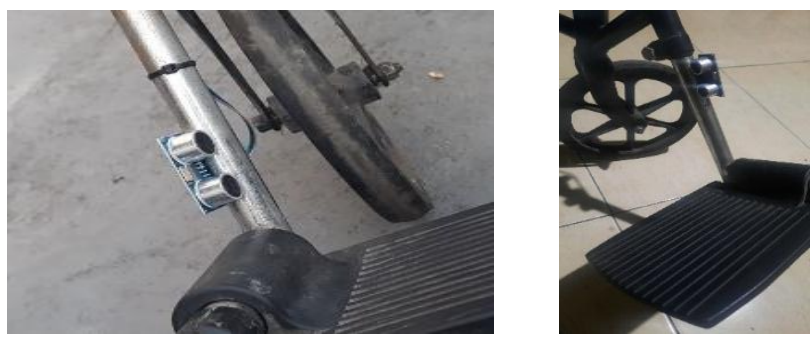

Figure 4. Placement Position of Ultrasonic Sensor on Footrest Pipe

Figure 4 shows the position of ultrasonic sensor on the right and left side pipes of the footrest holder. Ultrasound sensors are placed not facing each other to avoid confusing for the expected data reading. Figure 5 shows the placement of the E18-D80NK Proximity sensor. The sensor is placed on the right side of the wheelchair which is used to detect the presence of the user while sitting in a wheelchair.
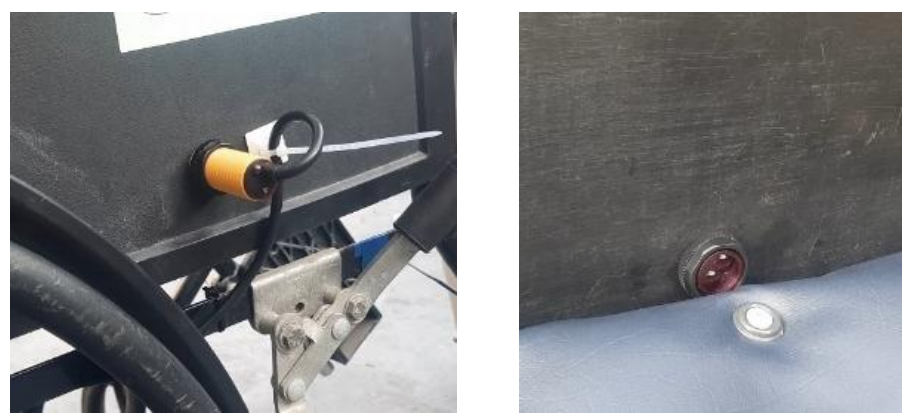

Figure 5. Proximity Sensor E18-D80NK

Table 1. shows the relationship between the Wemos D1 mini pins and the components used. 
International Journal of Applied Sciences and Smart Technologies

Volume 3, Issue 2, pages 171-184

p-ISSN 2655-8564, e-ISSN 2685-9432

Table 1. Pins on Wenos D1 mini and Components

\begin{tabular}{ccc}
$\begin{array}{c}\text { Wemos D1 } \\
\text { mini Pin }\end{array}$ & Components & Pin I/0 Components \\
\hline A0 & $\begin{array}{c}\text { Proximity E18-D80NK } \\
\text { Sensor }\end{array}$ & In \\
\hline D0 & infrared Sensor & VCC $:$ Infrared Sensor \\
\hline D1 & LCD, MPU-6050 & SCL \\
\hline D2 & LCD, MPU-6050 & SDA \\
\hline D3 & Buzzer & Out \\
\hline D5 & Ultrasonik Sensor & In \\
\hline D6 & Ultrasonik Sensor & In \\
\hline D7 & Ultrasonik Sensor & In \\
\hline D8 & Ultrasonik Sensor & GND : LCD, infrared \\
\hline GND & LCD, infrared Sensor, \\
& buzzer & Lensor, buzzer \\
\hline 5V & LCD & VCC
\end{tabular}

\subsection{Flowchart}

The flow chart used to detect the falling down position of wheelchair users with or without wheelchairs can be seen in Figure 6. 


\section{International Journal of Applied Sciences and Smart Technologies}

Volume 3, Issue 2, pages 171-184

p-ISSN 2655-8564, e-ISSN 2685-9432

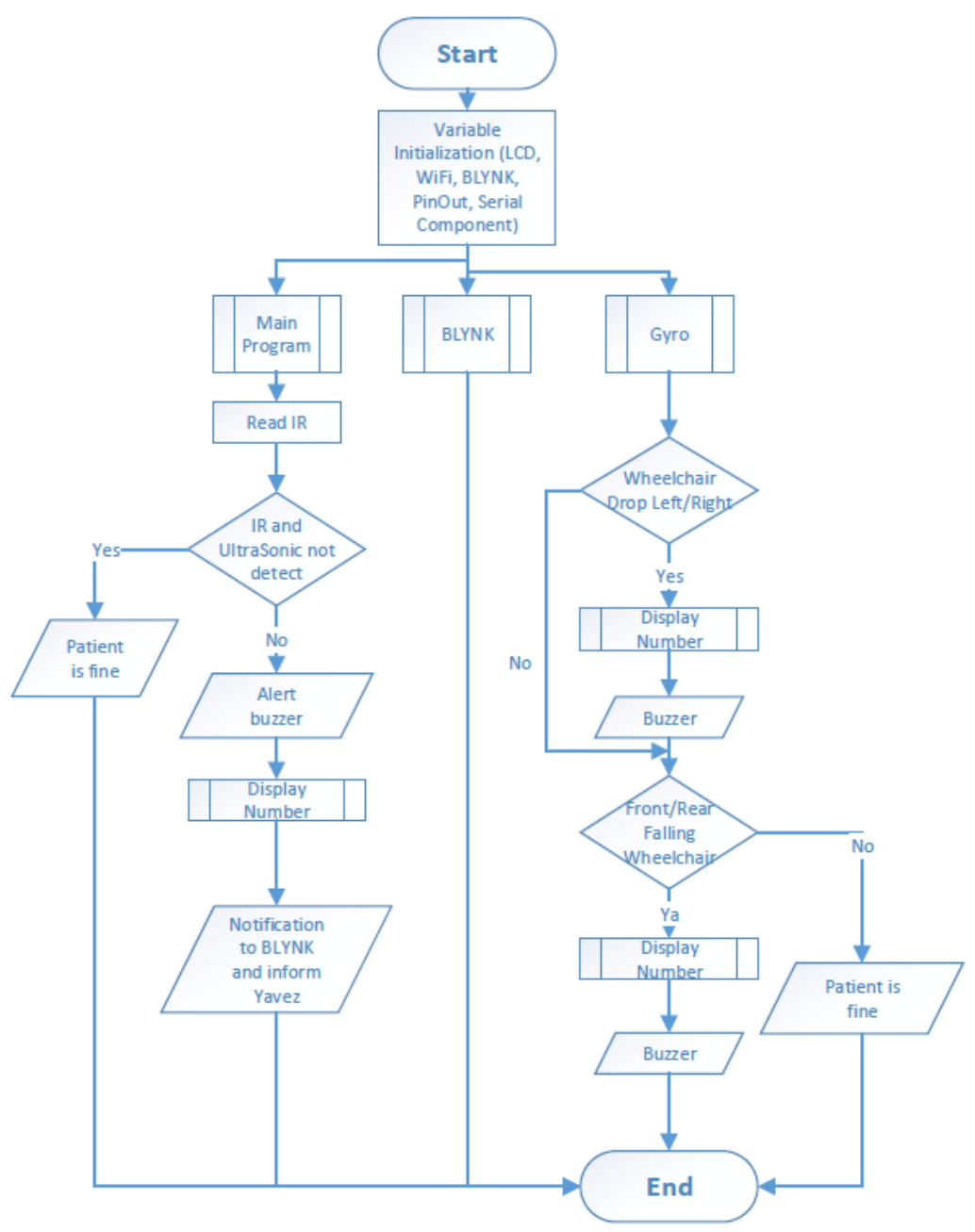

Figure 6. Flowchart

Figure 6. Flowchart starts with initializing variables, LCD, Wifi, BLYNK, Pinout and serial components. The next process is to run the BLYNK, Main Program and Gyro functions. The Main Program is executed to read the E18-D80NK IR or Proximity sensor. If the IR and Ultrasonic Sensors detect a wheelchair user, the LCD will display the words "Patient is fine". Furthermore, if the IR sensor does not detect a sitting user and the ultrasonic does not detect the user's legs, then the buzzer will sound and perform the display number function. The display number function is to send a notification to the BLYNK server as an emergency condition which will display information telephone numbers that can be contacted on the LCD. 


\section{International Journal of Applied Sciences and Smart Technologies}

Volume 3, Issue 2, pages 171-184

p-ISSN 2655-8564, e-ISSN 2685-9432

When the gyro function is run, it will detect the position of the wheelchair when it falls down to the left side, right side, forward side or backward side. If the wheelchair is dropped, the display number function will be executed and the buzzer will sound as a warning sign of an emergency wheelchair user and vice versa if it does not detect the falling down position, the LCD will display that the user is fine.

\section{Results and Discussions}

\subsection{MPU-6050 Sensor Test Results For Falling Down Conditions With Wheelchairs}

The test is carried out to get a value that can be used as a reference when the wheelchair is in a fallen condition and it is necessary to send a notification alert to BLYNK. The sensor has an $\mathrm{X}, \mathrm{Y}$, and $\mathrm{Z}$ axis that will read the degree value obtained when the wheelchair is dropped. The degree value obtained is recorded and used as a reference for the direction of falling the wheelchair. Please see Figure 7.

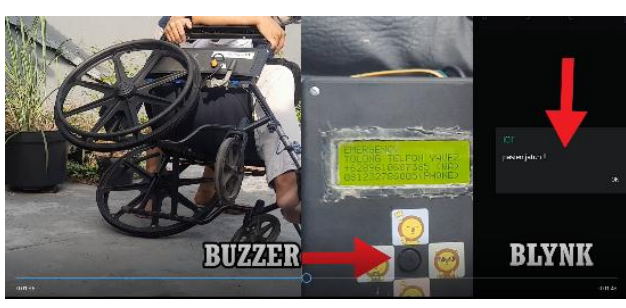

(a)

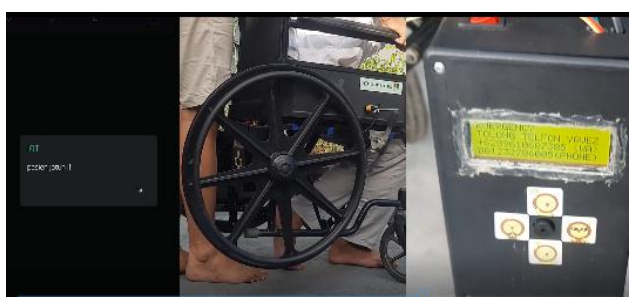

(c)

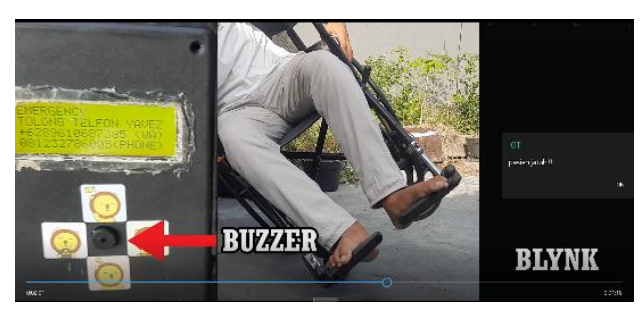

(b)

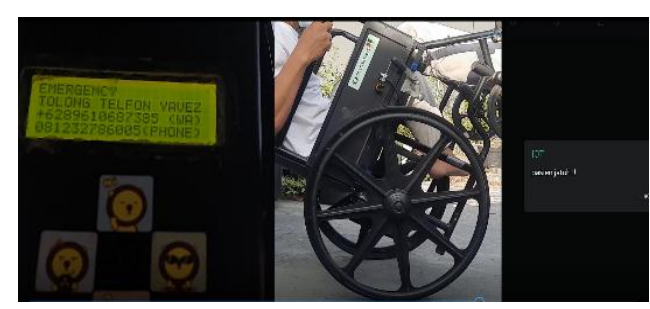

(d)

Figure 7. Testing the MPU-6050 Sensor on a wheelchair (a) Dropped to the left, (b) Dropped to the right, (c) Dropped forward, (d) Dropped backwards 


\section{International Journal of Applied Sciences and Smart Technologies}

Volume 3, Issue 2, pages 171-184

p-ISSN 2655-8564, e-ISSN 2685-9432

Table 2. Reading of the MPU-6050 Axis Value on a wheelchair

\begin{tabular}{lccc}
\hline \multicolumn{1}{c}{ Position } & X-axis value & Y-axis value & Z-axis value \\
\hline Upright & $100^{\circ}$ & $216^{\circ}$ & $97^{\circ}$ \\
\hline Fall left & $135^{\circ}$ & $181^{\circ}$ & $91^{\circ}$ \\
\hline Fall right & $53^{\circ}$ & $1^{\circ}$ & $89^{\circ}$ \\
\hline Fall forward & $106^{\circ}$ & $255^{\circ}$ & $148^{\circ}$ \\
\hline Fall backward & $115^{\circ}$ & $103^{\circ}$ & $26^{\circ}$ \\
\hline
\end{tabular}

From the results of Table 2 it can be seen that the MPU-6050 sensor is very sensitive with the readable axis values changing easily. The sensor axis value can be change when the wheelchair moves quickly or there is a shock that affects the sensor. In determining the angle value used as a reference when the wheelchair is in a falling down position, it is taken only one of the axis values with the largest change in each falling down position. That only one axis value is taken as a reference because if you take all the three axes as a reference, there is a possibility that one of the value of the axes will have the same value which will cause confusion in determining the direction of the wheelchair's fall. The axes taken in each falling down condition can be seen in Table 3.

Table 3. Reference Axis for Falling Down Conditions

\begin{tabular}{lc}
\hline Fall Condition & Axis \\
\hline Left & $Y \leq 180^{\circ}$ \\
\hline Right & $X \leq 50^{\circ}$ \\
\hline Foward & $Z \leq 65^{\circ}$ \\
\hline Backward & $Z \geq 140^{\circ}$ \\
\hline
\end{tabular}

In accordance with Table 3 if the value of the axes is more than or less than the predetermined value, the wheelchair is considered to have fallen and wemos sends an emergency warning.

\subsection{The Test Results of Ultrasonic and Proximity E18-D80NK Sensors for Falling Down Conditions without the Wheelchair}

The test was carried out with a user sitting in a wheelchair and performing an emergency fall without a wheelchair. Two Ultrasonic sensors on the right and left sides of the footrest and Proximity E18-D80NK on the right side of the wheelchair will detect 


\section{International Journal of Applied Sciences and Smart Technologies}

Volume 3, Issue 2, pages 171-184

p-ISSN 2655-8564, e-ISSN 2685-9432

the presence or absence of a wheelchair user. The test starts from a wheelchair where there is no one at first time, then the footrest is open and both sensors detect it as a normal condition.

Both sensors will send an unsafe signal when the ultrasonic sensor detects no user's foot or foot object and the Proximity E18-D80NK sensor on the right side also detects no thigh object from the user. The test results can be seen in Table 4.

Table 4. The Test Results of Ultrasonic and Proximity E18-D80NK sensors to detect the presence of wheelchair users

\begin{tabular}{|c|c|c|c|}
\hline Sensor & $\begin{array}{c}\begin{array}{c}\text { Detect or Not } \\
\text { detect }\end{array} \\
\end{array}$ & Object & $\begin{array}{c}\text { Wheelchair } \\
\text { users condition }(*)\end{array}$ \\
\hline $\begin{array}{c}\text { Ultrasonik } \\
\text { Proximity E18-D80NK } \\
\end{array}$ & $\begin{array}{c}\text { Detect } \\
\text { Not detect }\end{array}$ & $\begin{array}{c}\text { Footrest } \\
- \\
\end{array}$ & No wheelchair users \\
\hline $\begin{array}{c}\text { Ultrasonik } \\
\text { Proximity E18-D80NK }\end{array}$ & $\begin{array}{l}\text { Detect } \\
\text { Detect }\end{array}$ & $\begin{array}{c}\text { Legs } \\
\text { Upper thigh }\end{array}$ & Wheelchair user detected \\
\hline $\begin{array}{c}\text { Ultrasonik } \\
\text { Proximity E18-D80NK } \\
\end{array}$ & $\begin{array}{l}\text { Not detect } \\
\text { Not detect }\end{array}$ & - & $\begin{array}{l}\text { The wheelchair user in a } \\
\text { falling down position }\end{array}$ \\
\hline $\begin{array}{c}\text { Ultrasonik } \\
\text { Proximity E18-D80NK }\end{array}$ & $\begin{array}{l}\text { Not detect } \\
\text { Detect }\end{array}$ & $\stackrel{-}{\text { Upper thigh }}$ & $\begin{array}{l}\text { Wheelchair user detected } \\
\text { in fine condition }\end{array}$ \\
\hline
\end{tabular}

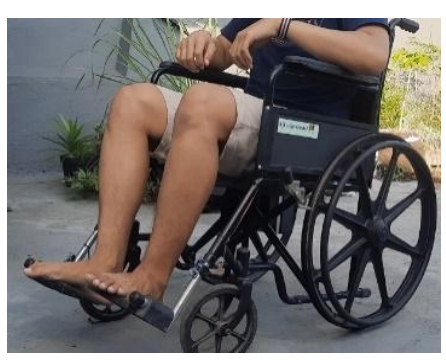

(a)

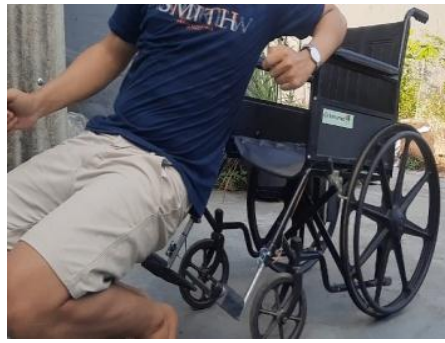

(b)

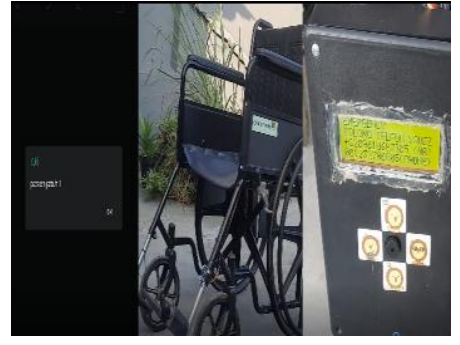

(c)

Figure 8. Testing of Ultrasonic and Proximity E18-D80NK Sensors (a) The sensor detects the presence of the user, (b) The user falls down in front of the wheelchair then the sensor can't detect the user, (c) Wemos sends emergency message

Figure 8 shows several positions when the sensor detects and does not detect the presence of a wheelchair user. Figure 8(a) shows an active ultrasonic sensor blocked by the legs of a wheelchair user and an active proximity sensor blocked by a seated user. Figure 8(b) shows the user falling towards the front of the wheelchair and the wheelchair position does not change. In moments later the ultrasonic sensor detects that 


\section{International Journal of Applied Sciences and Smart Technologies}

Volume 3, Issue 2, pages 171-184

p-ISSN 2655-8564, e-ISSN 2685-9432

the wheelchair user's legs are not blocked and the Proximity E18-D80NK sensor is not blocked by the wheelchair user's thigh. Figure 8(d) shows the system detects the user's emergency situation and sends a message to the previously saved mobile number. From the test results above, it can be concluded that the ultrasonic sensor and Proximity E18D80NK sensors function properly when detecting or not detecting the presence of wheelchair users.

\subsection{Notification Delivery Test Results}

The test aims to find out how far the recipient of the emergency warning can receive notification of an emergency message from the location of the wheelchair user. Notifications are sent by the Wemos D1 mini Wifi Module and utilize the BLYNK application platform as a recipient of emergency warnings for wheelchair users. Testing is done by turning on BLYNK to receive notifications.

To test the mileage for sending notifications, it is carried out as follows: the device that receives the notification of an emergency is placed in a predetermined location, then a test of receiving the notification of an emergency is carried out. The wheelchair was placed on the Kalijudan campus of Widya Mandala Catholic University Surabaya, which is located in Tambaksari District in the East Surabaya area. The results of sending and receiving notifications can be seen in Table 5.

Table 5. Testing the Mileage of Notification Delivery

\begin{tabular}{llccc}
\hline No & $\begin{array}{l}\text { Distance from } \\
\text { wheelchair } \\
\text { location }(\mathrm{km})\end{array}$ & District or Location & Area & $\begin{array}{c}\text { Message } \\
\text { Sent or not sent }\end{array}$ \\
\hline 1. & $8,5 \mathrm{~km}$ & Sukolilo & East Surabaya & Sent \\
\hline 2. & $10 \mathrm{~km}$ & Pabean Cantian & North Surabaya & Sent \\
\hline 3. & $13 \mathrm{~km}$ & Gayungan & South Surabaya & Sent \\
\hline 4. & $19 \mathrm{~km}$ & Lakarsantri & Surabaya Barat & Sent \\
\hline 5. & $26,1 \mathrm{~km}$ & Kota & Gresik & Sent \\
\hline 6. & $28 \mathrm{~km}$ & Icon Mall Gresik & Gresik & Sent \\
\hline 7. & $32 \mathrm{~km}$ & Plaza Sidoarjo & Sidoarjo City & Sent \\
\hline 8. & $34,8 \mathrm{~km}$ & Sidoarjo Fishing & Sidoarjo & Sent \\
\hline 9. & $37 \mathrm{~km}$ & Rest area at Toll Road & Mojokerto & Sent \\
\hline 10. & $48 \mathrm{~km}$ & Mojokerto & Miwi Kimia Paper \\
& & Mills Tol Road & Mojokerto & \\
\hline
\end{tabular}




\section{International Journal of Applied Sciences and Smart Technologies}

Volume 3, Issue 2, pages 171-184

p-ISSN 2655-8564, e-ISSN 2685-9432

From the above test, it can be concluded that the user can receive emergency notifications in all places with the condition that the device must be connected to the BLYNK server and connected to the internet.

\section{Conclusion}

The conclusion from the measurement and testing results are as follows:

a. The value read by the MPU-6050 sensor is taken one axis for each direction when the wheelchair was falling down, $\mathrm{Y} \leq 180^{\circ}$ for left falling down, $\mathrm{X} \leq 50^{\circ}$ for right falling down, $\mathrm{Z} \leq 65^{\circ}$ for forward falling down and $\mathrm{Z} \geq 140^{\circ}$ for backwards falling down.

b. The Ultrasonic sensor works well for detecting the presence of user's legs and the E18-D80NK proximity sensor works well for detecting the position of the user who is sitting in a wheelchair.

c. Receiving notifications through the BLYNK server works well, not affected by distance provided there is an internet connection connected to the device.

\section{References}

[1] D. M. Putri, "Mengenal Wemos D1 Mini Dalam Dunia IoT," Ilmu Teknologi dan Informasi, 1, 2-4, 2017.

[2] Baktikominfo, Pengertian, fungsi dan kelebihan accelerometer yang tak banyak orang ketahui, https://www.baktikominfo.id/id/informasi/pengetahuan/pengertian_fungsi_dan_kel ebihan_accelerometer_yang_tak_banyak_orang_ketahui-785 (Accessed: 22/11/2020).

[3] R. T. Asnada dan Sulistyono, "Pengaruh Inertial Measurement Unit (IMU) MPU6050 3-Axis Gyro dan 3-Axis Accelerometer pada Sistem Penstabil Kamera (Gimbal) Untuk Aplikasi Videografi." 11 (1), 48-55, 2020.

[4] F. N. Riyadi, "Perancangan Pendeteksi Banjir menggunakan Sensor Water Level berbasis PLC Schneider TM221CE16R dan SMS Gateaway.” 26-27, 2018.

[5] Nyebarilmu, Mengenal aplikasi blynk untuk fungsi IOT, https://www.nyebar ilmu.com/mengenal-aplikasi-blynk-untuk-fungsi-iot/ (Accessed: 10/11/2020) 


\section{International Journal of Applied Sciences and Smart Technologies}

Volume 3, Issue 2, pages 171-184

p-ISSN 2655-8564, e-ISSN 2685-9432

[6] S. M. Sari, "Aplikasi Sensor Ultrasonik Srf04 Dan Sensor Proximity Pada Level Pengisian Tangki Air Berbasis Atmega8535,”25-26, 2015.

[7] Muslimin dan Darul, "Sistem Pengaman Kursi Roda Elektrik dari Benturan Melalui Evaluasi Sensor Jarak.” https://repository.its.ac.id/id/eprint/46208, 2017.

[8] Y. Ji, J. Hwang, and E. Y. Kim, "An intelligent wheelchair using situation awareness and obstacle detection," Procedia, Social and Behavioral Sciences, 97, 620-628, 2013.

[9] Miachi, "A study of Aware Wheelchair with sensor networks for avoiding Two Meters Danger." Procedia, 1004-1010, 2016. 